\title{
The effect of escape gaps of cylinder folding traps on fish catch at the coastal waters of Tuban Regency
}

\author{
Farrel Nafis Adyatama ${ }^{1}$, Ghassan Nurul Huda ${ }^{1}$, Nahla Alfiatunnisa ${ }^{1}$, Faizal Rachman ${ }^{1}$, \\ Supardjo Supardi Djasmani ${ }^{1}$, Riza Yuliratno Setiawan ${ }^{1}$, Suwarman Partsuwiryo ${ }^{1}$, \\ Djumanto $^{1}$, Eko Setyobudi ${ }^{1 *}$ \\ ${ }^{1}$ Fisheries Department, Faculty of Agriculture, Universitas Gadjah Mada, Indonesia
}

\begin{abstract}
The purpose of this study is to determine the effect of the escape gap of cylinder folding trap on catch per unit effort (CPUE), trap rate, composition, and size of fish caught in the coastal waters of Tuban Regency. The research was conducted in November 2019 by deploying 60 units in ten experimental fishing trips at different locations. The traps were 20 units without escape gap, 20 units with an escape gap of $3 \mathrm{~cm} \times 6 \mathrm{~cm}$, and 20 units with an escape gap of $4 \mathrm{~cm} \times 7 \mathrm{~cm}$. Overall, the experiments resulted in a collection of 22 species of marine organisms, such as swimming crabs ( $33 \%$ of total weight), snails, shrimps, crabs, fishes $(55 \%$ of total weight), and cuttlefish. The highest CPUE was found for the traps with escape gaps of $4 \mathrm{~cm} \times 7 \mathrm{~cm}$, i.e., $9.18 \mathrm{gr} /$ trap/trip. There was no significant difference in the total catch, the weight of catches, trap rate, and catch per unit effort (CPUE) among the three types of traps.
\end{abstract}

\section{Introduction}

Tuban Regency East Java has a sea area of $65 \mathrm{~km}$ includes the Districts of Palang, Tuban, Jenu, Tambakboyo, and Bancar [1]. According to these geographical conditions, marine fisheries production in Tuban Regency is quite abundant, exceeding the needs of fish consumed by the community. The high potential of fisheries in the Tuban Regency causes many coastal communities to depend on fishing activities for their livelihoods. The high level of fisheries activity in the Tuban Regency causes the exploitation of marine resources to be quite immense. Therefore, it is necessary to properly carry out the fishing activities to minimize the risk of resources extinction.

The Tuban waters area in the Java Sea is included in the Fisheries Management Area (WPP) 712, which has a note with a red indicator (1.50), which means in the overfishing stage [2]. Therefore, it is important to make efforts to manage fish resources; hence there is no decrease in fish stocks which in the long term can cause the extinction of fish species [3]. The condition of fish stocks in Tuban waters continues to experience pressure due to the increasing number of fishers and their fishing activities. Various non-fishing industrial

\footnotetext{
*Corresponding author: setyobudi_dja@ugm.ac.id
} 
activities also cause the decline in fish stocks in these waters, mainly carried out between ships transporting coal, cement, or fuel oil which have a high risk of polluting the seas.

Managing the fisheries resources should be carried out with eco-friendly principles to keep fish stock sustainable by using environmentally friendly fishing gear. Several fishing gears were categorized as environmentally friendly fishing gear, including purse seines, traps, and gill nets. Environmentally friendly fishing gear has several criteria: high selectivity, not destroying habitat, producing good quality catch, being safe for consumers, not endangering biological resources, being socially acceptable, and producing low bycatch [4]. The fishing gear commonly used by fishermen in Indonesia is quite diverse, including payang (seine nets), gill nets, traps, and other tools. Bubu (fish trap) is quite commonly used in Tuban Regency. The use of fish traps for fish capture activities still often produces bycatch, i.e., undersized fish or non-economical fish. Therefore, the addition of an escape gap supposes as one of the solutions to reduce bycatch. Currently, the law regulates the size of crabs, swimming crabs, or lobsters that are allowed to be caught, namely PERMEN-KP No. 56 of 2016. The escape gaps modification was one of the fishing gear innovations that could increase the size of mangrove crab caught by folding traps [5].

Various types of traps have been used in Indonesia; either is a foldable fishing trap. The foldable fishing trap is practical, effortless to bring in numerous quantities, and the cost of production is relatively inexpensive. Foldable fishing traps have been used as fishing gear for seawater [6] and inland waters fisheries [7]. The traps commonly used in Tuban Regency are box-shaped, while the cylinder folding traps are still rarely used. The fish traps used by fishermen in this region are small and not operate throughout the year but mainly only used during the crab season. Therefore, this study is expected to provide information on the effectiveness of cylinder folding traps equipped with an escape gap in the caught crab and other fisheries resources.

\section{Material and method}

\subsection{Material}

The research was conducted in November 2019 by deploying 60 units of cylinder fishing traps in ten experimental fishing trips at different locations. The cylinder folding trap used in this study is the development of a fishing pot model, according to Alfiatunnisa's research in 2018 [6]. The traps were 20 unit= without escape gap (trap A), 20 units with an escape gap of $3 \mathrm{~cm} \mathrm{x} 6 \mathrm{~cm}$ (trap B), and 20 units with an escape gap of $4 \mathrm{~cm} \mathrm{x} 7 \mathrm{~cm}$ (trap C). The material used for the frame of the cylinder folding trap is iron with $4 \mathrm{~mm}$ in diameter and polyethylene net with 1.5 -inch in mesh size. The cylinder folding trap has a $30 \mathrm{~cm}$ diameter and $60 \mathrm{~cm}$ length, with $20 \mathrm{~cm}$ of funnel size. The other additional materials were GPS, scales with an accuracy of $1 \mathrm{~g}$, a ruler of $0.1 \mathrm{~cm}$, stationery, cameras, buckets, fisherman's motorboats, and fish baits. The cylinder folding trap design is shown in Figure 1. 


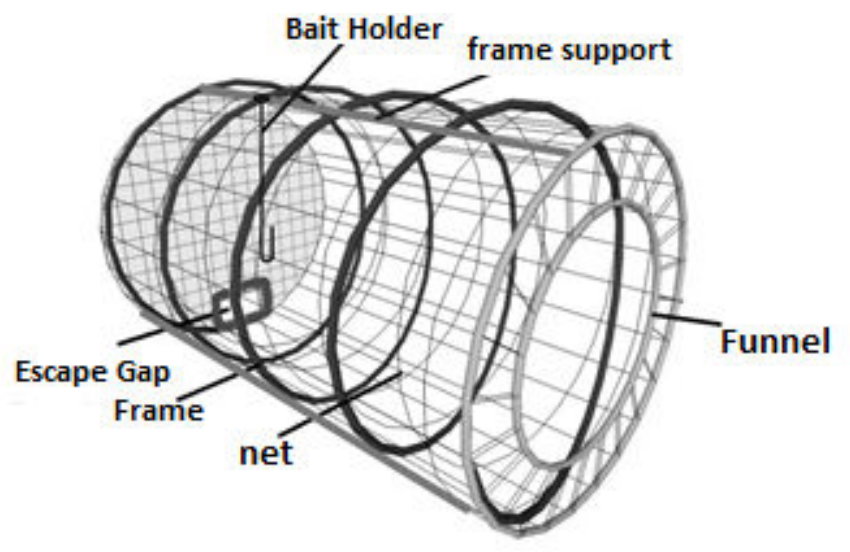

Fig. 1. The design of cylinder folding trap.

\subsection{Method}

The research was conducted in November 2019 by deploying 60 units in ten experimental fishing trips at about 1.5-1.8 nautical miles, with the most location point being 4.5 miles from the coastline (Figure 2). This research was executed at the Northern Coast of Java Sea, Socorejo Village, Jenu District, Tuban Regency, East Java. The research station is located in the Java Sea with ten different coordinate points. The experimental fishing method was conducted in this research; the operation was divided into three steps, i.e., setting the trap in the morning, immersing the trap for 24 hours, then hauling is done the next day. The location of the installation cylinder folding trap during the study showed in Figure 2.

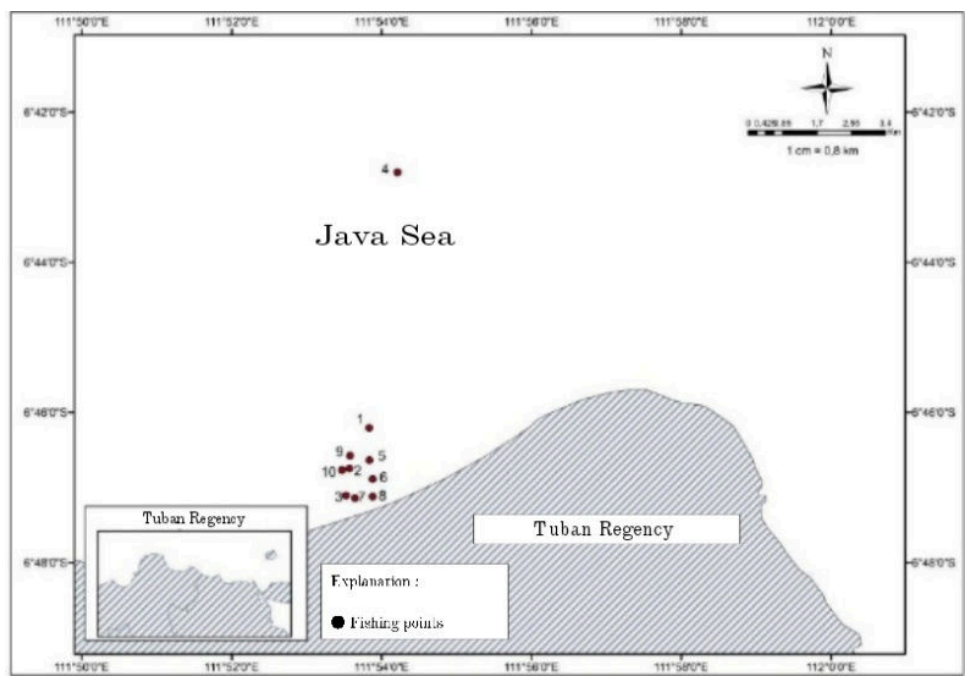

Fig. 2. The maps installation of cylinder folding Trap at the coastal waters of Tuban

The 60 units of cylinder folding trap were deployed at the bottom of the sea and connected to a rope of 620 meters. The arrangement of the traps is shown in Figure 3. 


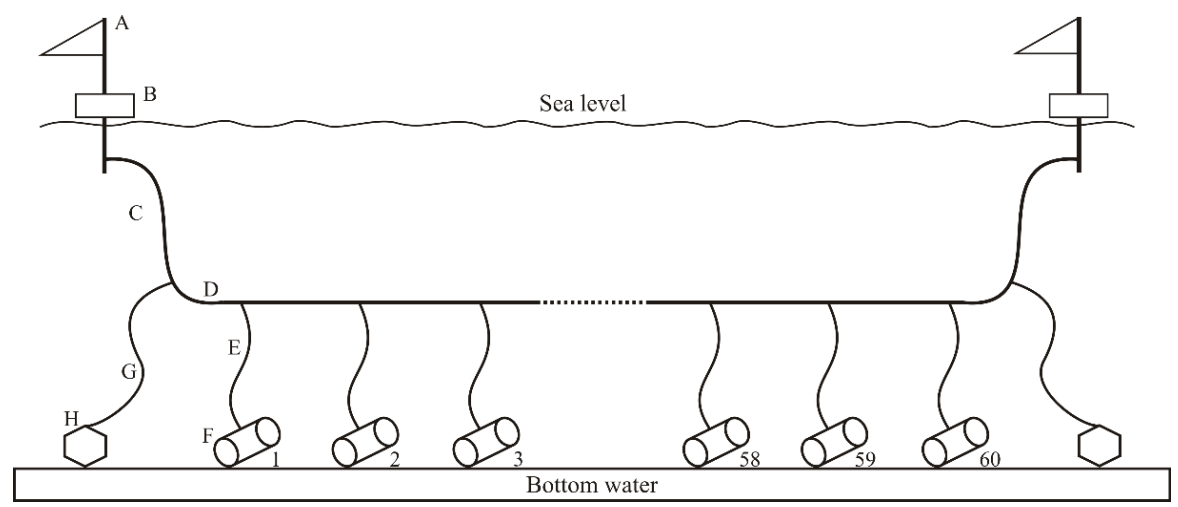

Fig. 3. The arrangement of traps during experimental fishing trips at the coastal waters of Tuban Regency.

Explanation :
A. Marker flag and lamp
E. Bridle
B. Buoy (Styrofoam)
F. Cylinder Folding Trap
C. Buoy Rope
G. Ballast Rope
D. Float Line
H. Ballast

\section{Result and discussion}

\subsection{Result}

A total of $4,46 \mathrm{~kg}$ of 22 fish and other marine faunas was collected from 60 traps in 10 fishing trips. The catch consisted of swimming crabs (Charybdis feratus), two spined arm swimming crab (Charybdis anisodon), long-eyed swimming crab (Podophthalmus vigil), blue swimming crab (Portunus pelagicus), Cresent pearch (Terapon jarbua), pig-faced leather jacket (Paramonacanthus choirocephalus), Japanese threadfin bream (Nemipterus japonicus), three-spined frogfish (Batrachomoeus trispinosus), duskytail grouper (Epinephelus bleekeri), spineless cuttlefish (Sepiella inermis), nessa mud snail (Nassarius dorsatus), Spotted hermit crab (Dardanus megistos), etc. The catch was dominated by fish (55\% of weight) and swimming crabs (33\%), while shrimps, cuttlefish and sea snails, and other crabs were minor contributors to the catch (Figure 4). The weight proportion of fish and nonfish in the catch for each type of trap appeared to be similar for traps without gap and trap with $3 \mathrm{~cm} \times 4 \mathrm{~cm}$ gap, while the traps with $4 \mathrm{~cm} \times 7 \mathrm{~cm}$ gaps showed the dominance of nonfish catch (Figure 5). However, the number of fish individuals appeared higher than the number of nonfish individuals for the traps without gap and trapped with a 3 $\mathrm{cm} \times 4 \mathrm{~cm}$ gap (Figure 6). 


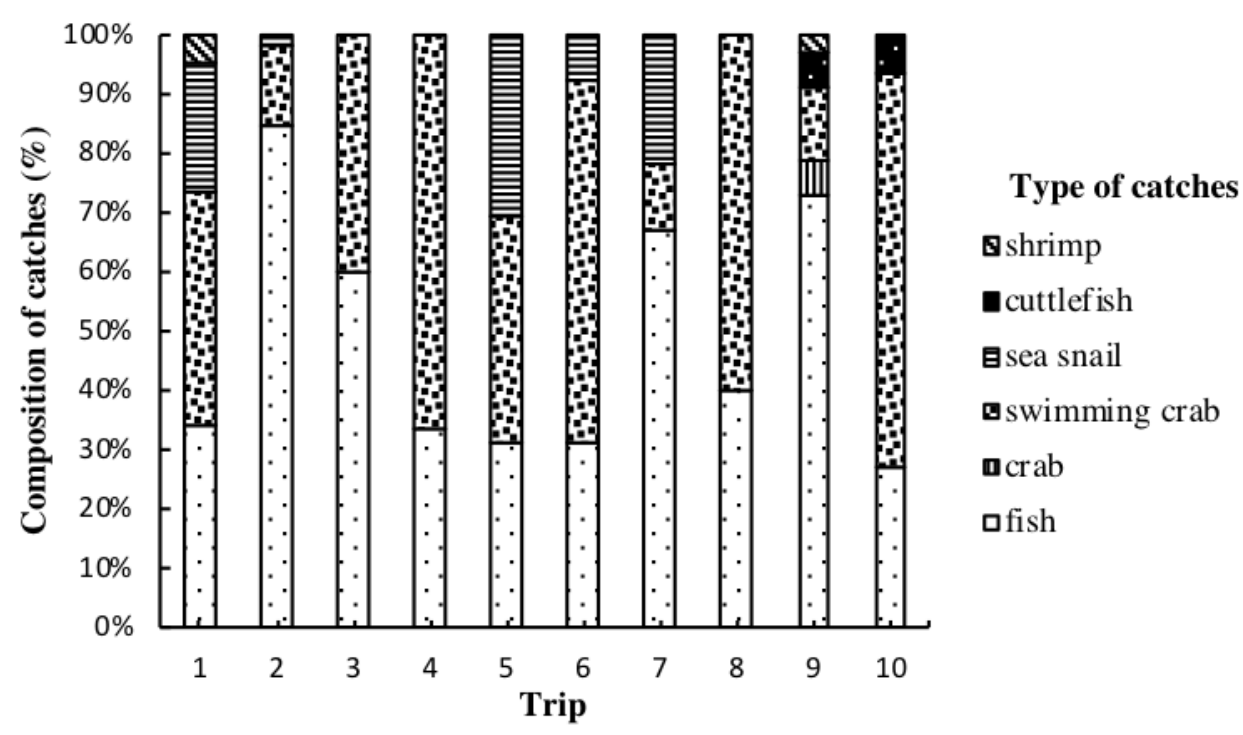

Fig. 4. Composition of catches with cylinder folding trap from experimental fishing in the coastal waters of Tuban Regency in November 2019.

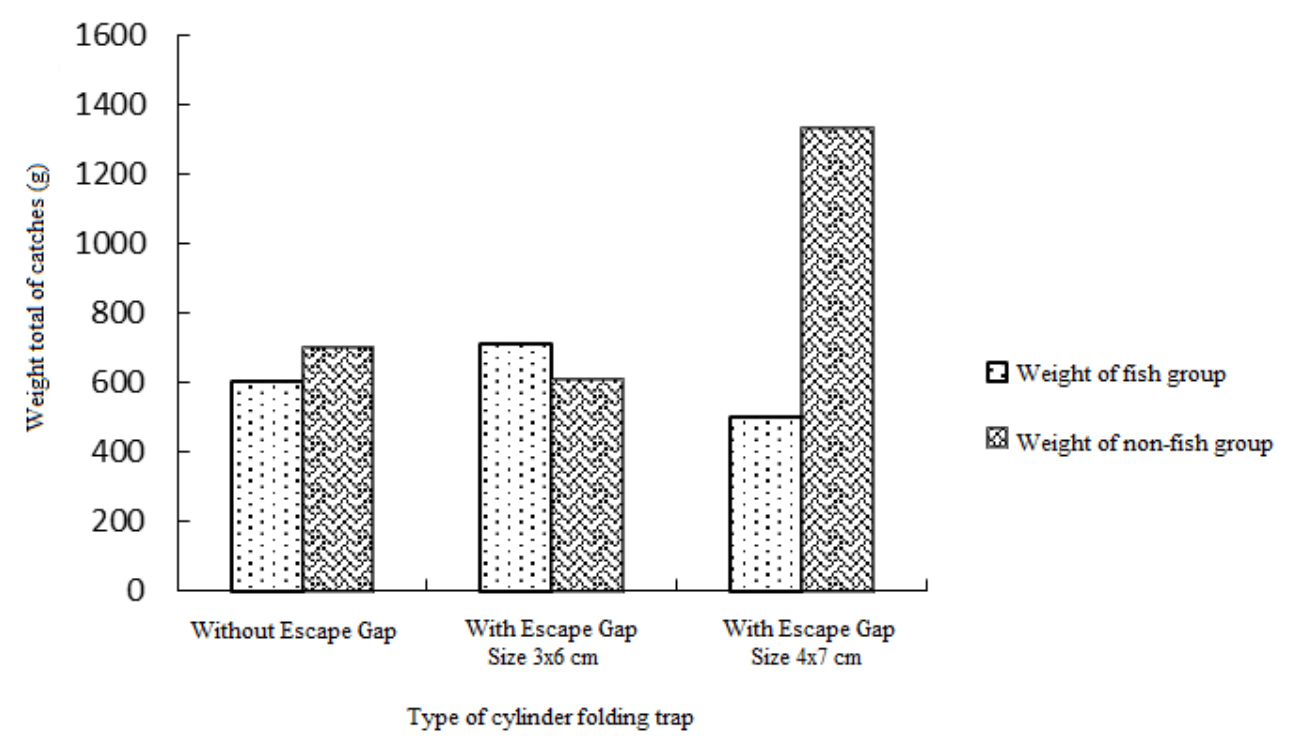

Fig. 5. Composition of fish and nonfish catches with cylinder folding trap from experimental fishing in the coastal waters of Tuban Regency in November 2019. 


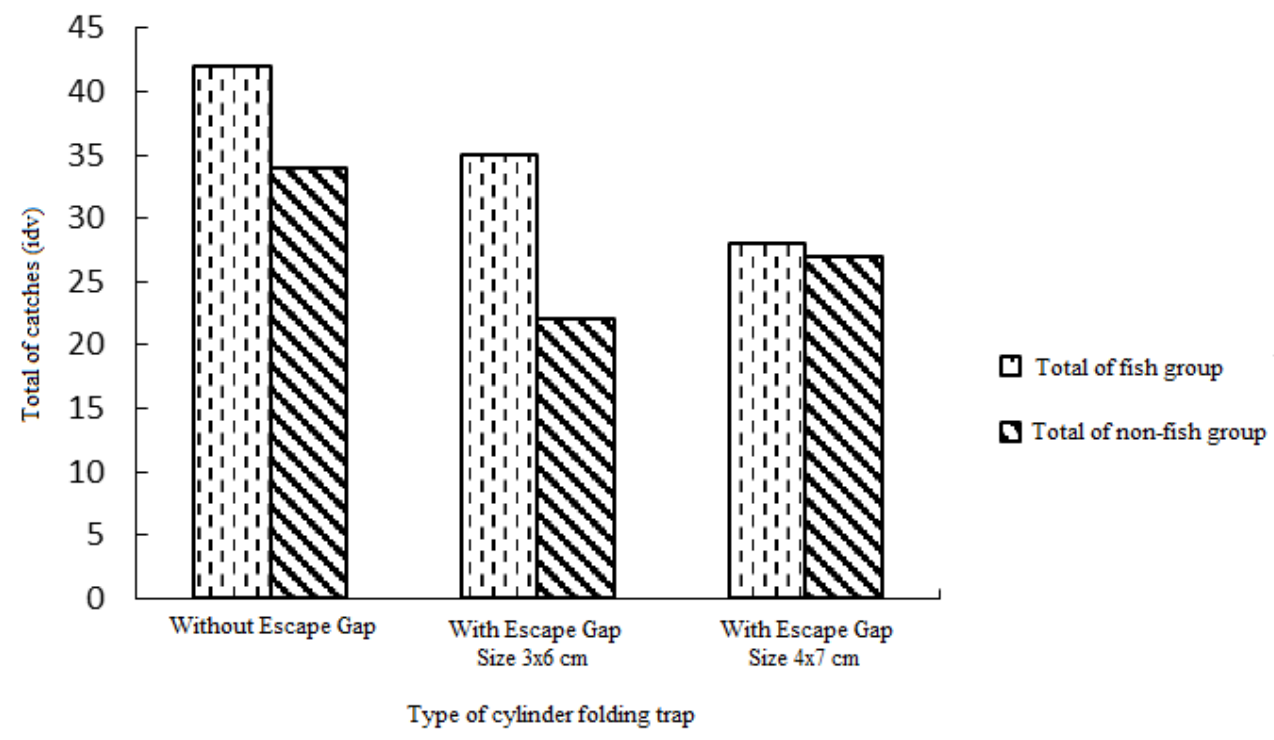

Fig. 6. The total weight of fish and nonfish catches with cylinder folding trap from experimental fishing in the coastal waters of Tuban Regency in November 2019.

Figure 6 shows that the nonfish in-cylinder folding trap with an escape gap of $4 \times 7 \mathrm{~cm}$ is heavier than the fish catch. Meanwhile, in-cylinder folding trap without escape gaps and cylinder folding trap with $3 \times 6 \mathrm{~cm}$ escape gaps, the weight of fish and nonfish are slightly different. The value of catch per unit effort showed in Table 1.

Table 1. The catch per unit effort (CPUE) of three different cylindrical folding traps during experimental fishing in the coastal waters of Tuban Regency in November 2019

\begin{tabular}{|c|c|c|c|c|c|c|}
\hline \multirow{2}{*}{ Trip } & \multicolumn{6}{|c|}{ Types of traps } \\
\cline { 2 - 7 } & \multicolumn{2}{|c|}{ without escape gap } & \multicolumn{2}{c|}{ with 3 cm x $4 \mathrm{~cm}$ gap } & \multicolumn{2}{c|}{ with 4 cm x cm gap } \\
\cline { 2 - 7 } & $\begin{array}{c}\text { Weight } \\
(\mathrm{g})\end{array}$ & $\begin{array}{c}\text { CPUE } \\
(\mathrm{g} / \text { trap })\end{array}$ & $\begin{array}{c}\text { Weight } \\
(\mathrm{g})\end{array}$ & $\begin{array}{c}\text { CPUE } \\
(\mathrm{g} / \text { trap })\end{array}$ & $\begin{array}{c}\text { Weight } \\
(\mathrm{g})\end{array}$ & $\begin{array}{c}\text { CPUE } \\
(\mathrm{g} / \text { trap})\end{array}$ \\
\hline 1 & 208,4 & 10,42 & 262,7 & 13,14 & 330,1 & 16,505 \\
\hline 2 & 47,9 & 2,395 & 142,4 & 7,12 & 93,4 & 4,67 \\
\hline 3 & 233,9 & 11,695 & 56,3 & 2,82 & 0 & 0 \\
\hline 4 & 3,2 & 0,16 & 74,5 & 3,73 & 21,6 & 1,08 \\
\hline 5 & 21,8 & 1,09 & 90,8 & 4,54 & 241 & 12,05 \\
\hline 6 & 224,2 & 11,21 & 242,9 & 12,15 & 164,7 & 8,24 \\
\hline 7 & 119 & 5,95 & 123,2 & 6,16 & 249,2 & 12,46 \\
\hline 8 & 64,6 & 3,23 & 48,8 & 2,44 & 58,9 & 2,95 \\
\hline 9 & 204,1 & 10,205 & 165 & 8,25 & 454,5 & 22,73 \\
\hline 10 & 174,4 & 8,72 & 114,9 & 5,745 & 223,3 & 11,17 \\
\hline Total & 1301,5 & 65,075 & 1321,5 & 66,075 & 1836,7 & 91,84 \\
\hline
\end{tabular}




\begin{tabular}{|c|c|c|c|c|c|c|}
\hline Average & 130,15 & 6,51 & 132,15 & 6,61 & 183,67 & 9,18 \\
\hline Standard deviation & 89,57 & 4,48 & 73,49 & 3,67 & 144,54 & 7,23 \\
\hline
\end{tabular}

Table 1 shows the average catch rate of cylinder folding traps. Treatment A is cylinder folding trap without escape gap, treatment B is cylinder folding trap with escape gap size $3 \times 6 \mathrm{~cm}$, and treatment $C$ is cylinder folding trap with escape gap size $4 \times 7 \mathrm{~cm}$. The cylinder folding trap without an escape gap is 6.5 catch per trap, a $3 \times 6 \mathrm{~cm}$ escape gap is $6.6 \mathrm{catch}$ per trap, and a $4 \times 7 \mathrm{~cm}$ escape gap is 9.12 catch per trap. The statistical analysis concluded that there is no significant difference in total CPUE (P-value $0.458>0.05$ at $95 \%$ confidence level). The total number of filled traps and the value of the trap rate showed in Table 2.

Table 2. The value of trap rate based on trip

\begin{tabular}{|c|c|c|c|c|c|c|}
\hline \multirow{2}{*}{ Trip } & \multicolumn{6}{|c|}{ Type of traps } \\
\cline { 2 - 7 } & \multicolumn{2}{|c|}{ without escape gap } & \multicolumn{2}{c|}{ with $3 \mathrm{~cm} \times 4 \mathrm{~cm}$ gap } & \multicolumn{2}{c|}{ with $4 \mathrm{~cm} \times 7 \mathrm{~cm}$ gap } \\
\cline { 2 - 8 } & $\begin{array}{c}\text { Filled } \\
\text { trap }\end{array}$ & Trap Rate & $\begin{array}{c}\text { Filled } \\
\text { trap }\end{array}$ & Trap Rate & $\begin{array}{c}\text { Filled } \\
\text { trap }\end{array}$ & Trap Rate \\
\hline 1 & 6 & $30 \%$ & 7 & $35 \%$ & 8 & $40 \%$ \\
\hline 2 & 6 & $30 \%$ & 4 & $20 \%$ & 5 & $25 \%$ \\
\hline 3 & 2 & $10 \%$ & 1 & $5 \%$ & - & - \\
\hline 4 & 1 & $5 \%$ & 1 & $5 \%$ & 1 & $5 \%$ \\
\hline 5 & 2 & $10 \%$ & 3 & $15 \%$ & 2 & $10 \%$ \\
\hline 6 & 3 & $15 \%$ & 2 & $10 \%$ & 2 & $10 \%$ \\
\hline 7 & 2 & $10 \%$ & 1 & $5 \%$ & 2 & $10 \%$ \\
\hline 8 & 1 & $5 \%$ & 1 & $5 \%$ & 1 & $5 \%$ \\
\hline 9 & 7 & $35 \%$ & 3 & $15 \%$ & 3 & $15 \%$ \\
\hline 10 & 4 & $20 \%$ & 2 & $10 \%$ & 2 & $10 \%$ \\
\hline Total & 34 & $170 \%$ & 25 & $125 \%$ & 26 & $130 \%$ \\
\hline Average & 3,4 & $17 \%$ & 2,5 & $13 \%$ & 2,89 & $14 \%$ \\
\hline
\end{tabular}

The number of traps filled with fish or other organisms for each type of trap ranged from 1 to 8 traps; this reflects the success rate of $5 \%$ to $40 \%$ (Table 2). The statistical analysis showed no significant difference between the treatment of escape gap based on the trap rate (A-Symp sig $0.570>0.05$ at $95 \%$ confidence level). 


\subsection{Discussion}

The addition of an escape gap on the cylinder folding trap is supposed to improve the ecofriendly fishing gear, as pointed in the Code of Conduct for Responsible Fisheries. A fishing pot or trap is an eco-friendly fishing gear because it does not damage the environment and is selective because it produces less bycatch and undersized catches [8]. Based on this experimental fishing, the total catches from three different treatments was $4.46 \mathrm{~kg}$ with 22 species. The total weight of nonfish groups is higher than the fish group. The design and the type of entrance will affect the number of catches and the success of fishing operations [9].

The cylinder folding trap without escape gaps obtains the most catches in fish and nonfish. Meanwhile, the cylinder folding trap with an escape gap size of $4 \times 7 \mathrm{~cm}$ obtains the most significant weight based on nonfish. Several factors that influence the number of the nonfish group are the bait used in the form of a pungent smell that is very attractive to animals such as crabs or crabs that rely on the sense of smell to find prey. Bait can affect the effectiveness of fish traps in catching fish. The bait's smell will be attracting the fish into the trap or fish pot. The crustacea's olfactory is very sensitive and detailed in locating the bait, which is the source of the scent of bait [10], [11].

Cylinder folding traps without escape gaps gain five times more undersize catches than large catches. A cylinder folding trap equipped with escape gaps can reduce the type and number of catches. One of the factors why traps with escape gaps still gain undersized fish is because they use the trap as a shelter. In addition, the bait used is durable enough so that the fish still want to be in the trap because the food is still there. The escape gap can even technically be used as an undersize or small fish [12]. The placement of the escape gap is an essential factor. The fish that entered the trap, especially the undersized fish, could move out quickly, and vice versa, could not enter through the escape gap. The placement of the escape gap should be following the fish behavior.

A cylinder folding trap with an escape gap measuring $4 \times 7 \mathrm{~cm}$ obtained an average trap rate of 1.5 times further than a cylinder folding trap without an escape gap and with an escape gap of $3 \times 6 \mathrm{~cm}$. Several factors can affect the trapping rate, including the installation location of the trap, environmental conditions, and season [13]. Moreover, the cylinder folding trap has a highly CPUE value rather than other traps. Based on these results, it can be concluded that in terms of the trap rate and CPUE value, the cylinder folding trap with an escape gap of $4 \times 7 \mathrm{~cm}$ has a quite good performance. Although CPUE is generally assumed to be comparable for relative fish abundance, it is a complex variable and depends strongly on various factors that could affect the value of CPUE [14], [15]. Temporal and spatial differences in the value of CPUE within areas to a wide-reaching could be expounded by changes in fishing methods, seasonal shifts to targeting migratory stocks, or fish spawning aggregations in specific locations [15].

The location of experimental fishing determines the catch composition and the overall amount of catch. According to Slack and Smith [16], cylinder traps or drum nets are more suitable for rivers or other flowing waters. The cylinder trap is more suitable for use in flowing waters because the position of the trap entrance is only on one side; hence, when the cylinder trap is installed against the flow of water, the cylinder trap will be more stable. In addition, cylinder traps have low stability in open water compared to other traps such as cubes or domes [16]. Cylinder folding traps operated on the seabed tend to be easier to rotate and move to follow the existing water currents.

In comparison, the cube or dome trap is more stable in the water because it has a flat bottom. The stability factor of the cylinder trap is what affects the effectiveness of the escape gap. The escape gap installed on the cylinder trap will rotate with the water flow so that small fish in the trap will have difficulty finding the escape gap. Several factors can 
affect the success of the escape gap installed in the trap, including the trap design, the location of the escape gap, the size of the escape gap, and the design of the escape gap [17].

In an analysis of ways to minimize the impact of fishing activities in the future, fish traps are identified as offering attractive qualities in terms of both sustainable development and economic feasibility [18], [19]. Fish traps have low fuel needs, which means the costs become more affordable, and the probability of unwanted bycatch species for survival is high end. Depending on immersing time and depredation, the traps may capture fish alive and unharmed [19]. That means fishers could gain a higher price compared to the standard price for their catches. With various positive impacts both from an economic and environmental perspective, hopefully, the research on fishing traps can continue to be considered and developed for fishers.

\section{Conclusion}

Fish and crabs were the dominant catches obtained from the three types of cylinder folding trap. The highest number of catches in fish was obtained in-cylinder folding traps without escape gaps, while cylinder folding traps with $4 \times 7 \mathrm{~cm}$ escape gaps obtained the heaviest nonfish. The cylinder folding trap with an escape gap measuring $4 \times 7 \mathrm{~cm}$ obtains the highest catch rate value, $9.18 \mathrm{gr} / \mathrm{trap} / \mathrm{trip}$, and the cylinder folding traps without escape gaps obtain the highest average trap rate, $17 \%$. In contrast, the trap with escape gap sizes $3 \times 6$ and $4 \times 7$ obtained $13 \%$ and $14 \%$, respectively. Further research is still needed, such as the position of fishing gear to be more stable. Hence, the fishing gear can function optimally.

\section{References}

1. Local Government Agency of East Java, Potensi produk unggulan Jawa Timur, Tuban Regency ed (Local Government Agency of East Java, East Java, 2013)

2. A. Suman, F. Satria, B. Nugraha, A. Priatna, K. Amri, Mahiswara, J. Kebijak. Perikan. Ind., 10 (2018)

3. A. Suman, H.E. Irianto, F. Satria, K. Amri, J. Kebijak. Perikan. Ind., 8 (2016)

4. Directorate General for Marine Coast and Small Islands, Panduan jenis-jenis penangkapan ikan ramah lingkungan, 1st ed (in Bahasa Indonesia) (Bina Marina Nusantara, Jakarta, 2006)

5. A. Susanto, R. Irnawati, JPK, 2 (2012)

6. N. Alfiatunnisa, F Rachman, E Setyobudi, Djumanto, S. S. Djasmani, IOP Conf. Ser. Earth and Environ. Sci., 404, (2020)

7. H. C. Nugroho, M. W. Aji, N. Alfiatunnisa, S. Partosuwiryo, Djumanto, Rusmilyansari, E. Setyobudi, Trop. Wetland. J. 6, 2 (2020)

8. S. R. Ningtiyas, F. Rachman, E. Setyobudi, Djumanto, S. S. Djasmani, IOP Conf. Ser. Earth and Environ. Sci., 404 (2020)

9. M. V. Archdale, Crabs: Anatomy, Habitat, Ecologcal. Sig. Chapter 2 (2012)

10. R. Caesario, R. Yusfiandayani, Diniah, J. Teknol. Perikanan kelautan 7, 2 (2016)

11. A. Suhariyanto, F. Rachman, E. Setyobudi, R.Y. Setiawan, N. Alfiatunnisa, S.S. Djasmani, E3S Web Conf., 147 (2020)

12. A.M. Imetazzaman, Fishing traps of Halti Beel Natore Bangladesh (Bd FISH Features, Bangladesh, 2010) 
13. A. Al-Baz, J.M. Bishop, M. Al-Husaini, W. Chen, J. Appl. Ichthyol 34, 4 (2018)

14. J. Bishop, W. N. Venables, C. M. Dichmont, D. J. Sterling, ICES J. Mar. Sci., 65 (2008)

15. M. Vadziutsina, R. Riera, Fish. Res. 223, 1-12 (2020)

16. R.J. Slack-Smith, Fishing with traps and pots (FAO, Rome, 2001)

17. A. Kurniasih, R. Irnawati, A. Susanto, JPK 6, 2 (2016)

18. P. Suuronen, F. Chopin, C. Glass, S. Løkkeborg, Y. Matsushita, D. Queirolo, D. Rihan, Fish Res, 119 (2012)

19. D. Kopp, Y. Coupeau, B. Vincent, F. Morandeau, S. Mehault, J. Simon, PLoS ONE, 15 (2020) 